\title{
Bioremediation of Lead Contaminated Agricultural Soil using Klebsiella pneumoniae
}

\author{
${ }^{1 *}$ ATIKPO, E; ${ }^{2}$ IHIMEKPEN, NI \\ ${ }^{1 *}$ Department of Civil and Environmental Engineering, Faculty of Engineering, Delta State University, Oleh Campus, PMB 1, Abraka, \\ Delta State, Nigeria \\ ${ }^{2}$ Department of Civil Engineering, Faculty of Engineering, University of Benin, PMB 1154, Benin City, Nigeria \\ *Corresponding AuthorEmail: eguasbridge@gmail.com; eatikpo@delsu.edu.ng; Tel: +2348038665352 \\ ${ }^{2}$ Email:n.ihimekpen@uniben.edu; +2348032646454
}

\begin{abstract}
This study focused on the use of Klebsiella pneumoniae for bioremediation of lead $(\mathrm{Pb})$ contaminated agricultural soil used for sustainable farming. Atomic Absorption Spectrophotometer (GBC SensAAS, Model no. A6358) was used to measure the concentration of $\mathrm{Pb}$ in the soil. Results showed that the organism first reduced the initial concentration of lead from $181.41 \mathrm{mg} / \mathrm{kg}$ to below the maximum allowable limit of $100 \mathrm{mg} / \mathrm{kg}$ in 14 days. Analysis of variance (ANOVA) at $\mathrm{P}<0.05$ shows the significance for only single factors in the order of temperature and stirring frequency with $\mathrm{P}$ value of 0.0015 , volume of nutrient and mass of organism with $\mathrm{P}$ value of 0.0016 and $\mathrm{pH}$ with $\mathrm{P}$ value of 0.0018 . The factors were ranked in the order of stirring frequency, temperature, volume of nutrient, mass of organism and $\mathrm{pH}$ with their respective percentage contributions of $18.20 \%, 17.97 \%$, $17.57 \%, 17.52 \%$ and $16.88 \%$.
\end{abstract}

\section{DOI: https://dx.doi.org/10.4314/jasem.v24i5.11}

Copyright: Copyright (C) 2020 Atikpo and Ihimekpen. This is an open access article distributed under the Creative Commons Attribution License (CCL), which permits unrestricted use, distribution, and reproduction in any medium, provided the original work is properly cited.

Dates: Received: 22 March 2020; Revised: 18 April 2020; Accepted: 22 April 2020

Keywords: Lead, soil remediation, Klebsiella pneumoniae.

Soil plays an important part in the scheme of life. Hence, it is vital resource for life development on earth (Narayanan, 2007). Soil serves several functions in human society (Nwaugo et al., 2008), and can be regarded as a sit for national economic development (Atikpo, 2016). Soil is a resource for food and energy crops for human society as well as for the animal world needed for game reserves. It is a resource for diverse agricultural entrepreneurial activities require for sustainable development. Heavy metals are highly dangerous because they bioaccumulate in living things. Once ingested into the environment by any source, may spread to various ecological components (Njoku and Ngene, 2012). They find their ways to plants via their growth media - soil, air, nutrients by their roots or foliage (Okoronkwo et al., 2005). Growing plants in a polluted soil can accumulate the toxic metals at high concentration causing serious human health when consumed (Voustal et al., 1996; Alloway, 1990). Many heavy metals are biological poisons even at very low concentration. The toxic metals accumulate in organic matter component of soils and are taken-up, translocated by growing plants (Mukesh, 2008). Long term exposure to heavy metal leads to chronic problems like toxicological effect on kidney, mental lapse, liver and gastrointestinal tract, skin poisoning and harmful effect on the central nervous system (Lenntech, 2009). The threat that heavy metals pose to human, animal health and ultimately economic advancement is aggravated by their low environmental mobility and their long term persistence in the environment (Chamannejadian, 2011). Heavy metals alteration of soil is a major health concern needing preventive and remediation response to avoid its ecological consequences (Begun et al., 2009; Galiulin et al., 2002) which leads to developmental drawback. Therefore, this study focused on the use of Klebsiella pneumoniae for bioremediation of lead contaminated agricultural soil used for sustainable farming.

\section{MATERIALS AND METHOD}

Materials: Soil, McCartney bottles, hot plate, autoclave, measuring cylinder, microscope, wire loops, pipette, conical flasks, inoculating needles, refrigerator, whatman filter paper, petri dishes, beakers, cotton wool, incubator, Atomic Absorption Spectrophotometer.

Reagents: These include oxidase reagent, Lugo's iodine, hydrochloric acid, nitric acid, ethanol, Kovac's reagent, perchloric acid and sulphuric acid; methylene blue, crystal violent, hydrogen peroxide, sodium hydroxide and safranin. 
Soil Sampling: Soil samples were collected from heavy metals contaminated site at Amaonye forest in Ishiagu clan, Ebonyi State of Nigeria by using spatula and stored in polythene bag. The samples were aseptically transported to the laboratory at the Department of Micro Biology of the Delta State University, Nigeria for bacteriological analysis.

Agars/Nutrients Preparation: Sticking to manufacturers' design and the technique in Cheesebrough (2000), 28, 15, 24, and 65 grams of powered nutrient agar, Simon citrate agar, peptone water powder and triple sugar iron agar were respectively dissolved for ten minutes in one liter of distilled water. For 15 minutes, and at temperature of $121^{\circ} \mathrm{C}$ and pressure of $1.5 \mathrm{psi}$, the solutions were autoclaved and cooled to $45^{\circ} \mathrm{C}$ for use.

Characterization of Bio - sorbent: Using the pure plate method, $0.1 \mathrm{ml}$ from serial dilution of $10^{-1}, 10^{-3}$ and $10^{-}$ ${ }^{5}$ was inoculated into sterile Petri-dishes; and topped with nutrient agar (Cowan, 1993; Baron et al., 1994). The inoculated dishes were inverted and incubated at $37^{\circ} \mathrm{C}$ for 24 hours (Cheesebrough, 2000) and growth that developed were counted, recorded and sub cultured. The isolates were characterized and recognized using (Cowan and Steel, 1990; Holt et al., 1994) methods; and biochemical tests were conducted by following the methods in Cheesebrough (2000).

Factors screening for $2^{n}$ factorial Design of Experiment: Factorial design of experiment requires the imputation of lowest and highest values of factors into the requisite software. These values were obtained through initial screening of factors. To achieve this, harvested 24 hours old Klebsiella pneumoniae was inoculated into soil samples conditioned with varied values of factors: $2,4,6,8,10$ and $12 \mathrm{ml}$ dosage of nutrient, $1,2,3,4,5$, and $6 \mathrm{~g}$ of organism's mass, $10^{\circ} \mathrm{C}$, $20^{\circ} \mathrm{C}, 30^{\circ} \mathrm{C}, 40^{\circ} \mathrm{C}, 50^{\circ} \mathrm{C}$ and $60^{\circ} \mathrm{C}$ of temperature, 4,5 , $6,7,8$, and 9 of $\mathrm{pH}$ and $0,1,2,3,4$ and 5 per week (pw) of stirring frequency in thirty $50 \mathrm{ml}$ beaker containing $3 \mathrm{~g}$ of soil each (Atikpo, 2016). These experiments were conducted in triplicate making a total of ninety (90) experiments and in accordance to the method in (Lima et al., 2007); the average values were determined from their impact on the residual lead ion in soil with an Atomic Absorption Spectrophotometer (GBC SensAA, Model no A6358) at time 14 days.

Determination of Effects of Factors by Statistical Design of Experiment: The treatment of lead ions from the soil followed the batch experiment procedure in (Lima et al., 2007). The Design Expert version 7.0 was engaged in an experimental design of two levels, $2^{\mathrm{n}}$ factorial. Where $\mathrm{n}$ is the number of factors and were set at five (5) in this study. The factors were utilized to design a total of 32 experiments. These factors set as five independent variables were coded as -1 (low) and +1 (high) as shown in Table 1 and utilized as the experimental conditioners in thirty-two $50 \mathrm{ml}$ capacity beakers stipulated by the Design Expert 7.0 and each beaker containing $3 \mathrm{~g}$ of the soil samples. 24 hours old Klebsiella pneumoniae was harvested and inoculated in soils contained in each beaker for a period of 35 days (Atikpo, 2016). By this period, the bacterium was centrifuged from the soil, and the residual lead ion content determined with Atomic Absorption Spectrophotometer (GBC SensAA, Model no. A6358). The amount of the metal ion removed, removed with time, and the percentage removals were evaluated, using Equations (1), (2) and (3) respectively (Cleiton et al., 2011, Badmus et al., 2007).

$q=\frac{\left(C_{o}-C_{f}\right)}{m} \cdot V$
$\mathrm{q}_{\mathrm{t}}=\frac{\left(C_{o}-C_{t}\right)}{m} \cdot V$

$\%$ Removal $=\frac{\left(C_{o}-C_{f}\right)}{C_{o}} \cdot 100$

Where $\mathrm{q}$ is lead ion $(\mathrm{mg} / \mathrm{kg})$ removed; $\mathrm{q}_{\mathrm{t}}$ is lead ion $(\mathrm{mg} / \mathrm{kg})$ removed with time $\mathrm{t}, C_{0}$ is the initial concentration $(\mathrm{mg} / \mathrm{kg})$ of lead ion in contact with the bacterium, $C_{\mathrm{f}}$ is the final concentration $(\mathrm{mg} / \mathrm{kg})$ of lead ion, Vis soil volume $\left(\mathrm{m}^{3}\right)$ in contact with the bacterium; and $\mathrm{m}$ is the bacterium's mass expressed in (g).

The resultant laboratory data was analyzed with Design Expert version 7.0, to generate the requisite information for decision making.

Table 1. The High and Low Levels of Factors for Design

\begin{tabular}{llllll} 
Levels & \multicolumn{5}{c}{ Factors } \\
\cline { 2 - 6 } & Nutrient $(\mathrm{A})(\mathrm{ml})$ & Mass of Organism $(\mathrm{B})(\mathrm{g})$ & Temperature $(\mathrm{C})\left({ }^{\circ} \mathrm{C}\right)$ & $\mathrm{pH}(\mathrm{D})$ & Stirring Frequency $(\mathrm{E})(\mathrm{pw})$ \\
\cline { 2 - 7 } Low $(-1)$ & 8 & 1 & 30 & 7 & 4 \\
High $(+1)$ & 10 & 4 & 40 & 9 & 5 \\
\hline
\end{tabular}

\section{RESULTS AND DISCUSSION}

Characterization: Microbiological study carried out for the isolation and identification of organism revealed the selected organism from the biochemical characterization of the colony of $2.6 \times 10^{2} \mathrm{cfu} / \mathrm{ml}$ which developed after incubation. The bacterium was 
distinguished with the respective biochemical indications of positive gram stain, negative catalase, negative oxidase, positive indole, positive citrate, negative glucose, negative lactose, $\mathrm{H}_{2} \mathrm{~S}$ and motility as Klebsiella pneumoniae.
Statistical Study of Factors for Optimal Bioremediation: The experimental results of the percentage removal of lead by the organism as obtained based on the statistical design were recorded as shown in Table 2 and analyzed with Design Expert 7.0 .

Table 2. Experimental Result on Statistical Study of Factors

\begin{tabular}{|c|c|c|c|c|c|c|c|c|c|c|c|}
\hline Run & 1 & 2 & 3 & 4 & 5 & 6 & 7 & 8 & 9 & 10 & 11 \\
\hline$\%$ Removal & 50.43 & 70.44 & 64.23 & 70.43 & 70.23 & 76.32 & 70.32 & 70.54 & 70.42 & 50.01 & 64.38 \\
\hline Run & 12 & 13 & 14 & 15 & 16 & 17 & 18 & 19 & 20 & 21 & 22 \\
\hline$\%$ Removal & 73.35 & 64.23 & 73.57 & 73.93 & 73.67 & 70.32 & 64.21 & 70.11 & 50.64 & 50.86 & 64.37 \\
\hline Run & & 23 & 24 & 25 & 26 & 27 & 28 & 29 & 30 & 31 & 32 \\
\hline$\%$ Removal & & 45.52 & 64.78 & 70.43 & 64.78 & 70.65 & 64.32 & 64.78 & 64.56 & 73.24 & 50.43 \\
\hline
\end{tabular}

The useful analytical informative derivations are the goodness of fit parameters, analysis of variance (ANOVA), Pareto charts and factors' effects list. The ANOVA informed on the factors and their interactions significance through the displayed probability values. Reliability of model was confirmed by the model's coefficient of determination $\left(\mathrm{R}^{2}\right)$ and the adjusted $\mathrm{R}^{2}$. The respective high values of $R^{2}$ and the adjusted $R^{2}$ confirmed the model as adequate. Relying on the adequacy of model, the factors' effects lists and Pareto chart were generated. The relevance of the effects list is the revelation of the standardized effects and the percentage contributions of both the factors and their combinations. The Pareto chart permitted the detection of the factors and interaction effects of more relevance to the removal process by displaying the absolute values of the effects and drawn reference line. Any factor effect that extends beyond the reference line is significant. The placement of the significance of every factor and interaction depends on the value of the coefficient of each factor or its interaction (Pavan et al., 2007). The analysis indicated the model to be reliable. This was abundantly confirmed by the model's coefficient of determination $\left(\mathrm{R}^{2}\right)$ and the adjusted $R^{2}$ with their respective values of 0.9642 and 0.8149 shown in Table 3 .

\begin{tabular}{llll}
\multicolumn{4}{c}{ Table 3. Parameters for Model Adequacy } \\
\hline $\begin{array}{l}\text { Standard } \\
\text { Deviation }\end{array}$ & 3.64 & R-Squared & 0.9642 \\
Mean & 65.33 & Adjusted R-Squared & 0.8149 \\
C.V \% & 5.57 & Predicted R-Squared & - \\
& & Adequacy of & 0.0192 \\
PRESS & 2262.29 & $\begin{array}{l}10.101 \\
\text { Precision }\end{array}$ \\
\hline
\end{tabular}

The ANOVA conducted showed the single factors in the order of temperature and stirring frequency with $\mathrm{P}$ values of 0.0015 , volume of nutrient and mass of organism with $\mathrm{P}$ value of 0.0016 and $\mathrm{pH}$ with $\mathrm{P}$ value of 0.0018 significant at $95 \%$ confidence level $(\mathrm{P}<0.05)$; while none of the combined factors had significant effects since the probability value was greater than $0.05(\mathrm{P}>0.05)$. The ANOVA analysis showed that only the single factors were significant.
The Pareto chart revealed the ranking of these factors with their contributory values as shown in Figure 1. Factors favoring Klebsiella pneumoniae remediation capability were ranked in the order of stirring frequency, temperature, volume of nutrient, mass of organism and $\mathrm{pH}$ with their respective percentage contributions of $18.20 \%, 17.97 \%, 17.57 \%, 17.52 \%$ and $16.88 \%$ as shown in Table 4 .

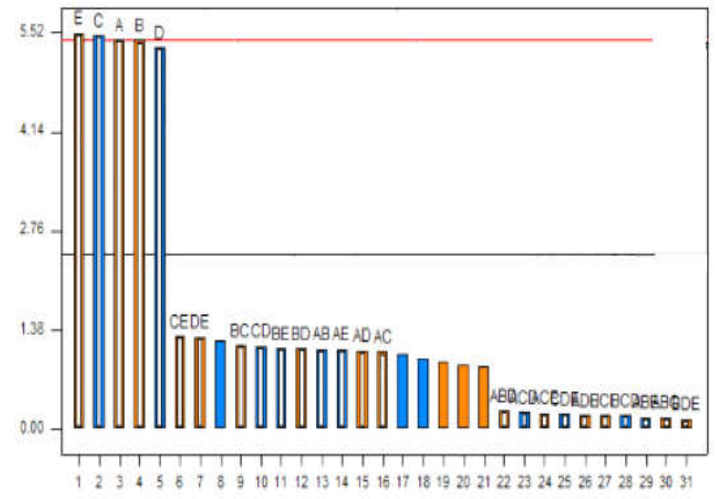

Rank

Fig 1. Pareto Chart Ranking of Selected Factors

\begin{tabular}{lll}
\multicolumn{3}{c}{ Table 4. Summary Parameters } \\
\hline \multicolumn{3}{c}{$\mathrm{R}^{2}=0.9642$ Adj. $\mathrm{R}^{2}=0.8149$} \\
\hline Ranking & $\begin{array}{l}\mathbf{P}<\mathbf{0 - 0 5} \text { at } \mathbf{9 5 \%} \\
\text { confidence level }\end{array}$ & $\mathbf{\%}$ \\
& Contribution \\
\hline $\mathrm{SF}$ & 0.0015 & 18.20 \\
$\mathrm{~T}$ & 0.0015 & 17.97 \\
$\mathrm{VN}$ & 0.0016 & 17.57 \\
$\mathrm{MO}$ & 0.0016 & 17.52 \\
$\mathrm{pH}$ & 0.0018 & 16.88 \\
Volume of Nutrient, MO: Mass of Organism, T: Temperature, \\
\multicolumn{3}{c}{ SF: Stirring Frequency. }
\end{tabular}

Conclusion: Contaminated soil leads to contaminated food and ultimately sickly society. Therefore, a way of making contaminated soil uncontaminated by applying Klebsiella pneumoniae for soil remediation was the focus of this study. The organism was found to reduce the initial concentration of lead from $181.41 \mathrm{mg} / \mathrm{kg}$ to below the allowable concentration of $100 \mathrm{mg} / \mathrm{kg}$. This concentration reduction first occurred on the $14^{\text {th }}$ day and further reduced with time. This Knowledge is vital for soil remediation planning and practice. 


\section{REFERENCES}

Alloway, BJ (1990). Soil Processes and the Behaviour of Metals, in: Heavy Metals in Soils, Aloway, BJ (ed) Blackie and Son Limited, Bishopbriggs, Glasgow G 64 2N2

Atikpo, E (2016). Spatial Distribution and Attenuation of Heavy Metals Pollution in AmaonyeIshiagu Forest Soils, A PhD Thesis Submitted to the Department of Civil Engineering, University of Benin, Benin City, Nigeria.

Badmus, MAO; Audu, TOK; Anyata, BU (2007). Removal of Lead Ion from Industrial Wastewaters by Activated Carbon Prepared from Periwinkle Shells (Typanotonusfuscatus). Turk. J. Environ. Eng. Sci. 31:251-263.

Baron, EJ; Peterson, LR; Finegold, SM (1994). Bailey and Scotts Diagnostic Microbiology, Ninth Edition. Mosby, Baltimore.

Begum, A; Ramaiah, M; Harikrishna, O; Irfanulla, K; Veena, K (2009). Analysis of Heavy Metal Concentrations in Soil and Litchen from Various Localities of Hosur Road, Bangalore, India. $J$. Chem. 6(1):13-22.

Chamannejadian, A; Moezzi, AA; Sayyad, GA; Jahangirl, A; Jafarnejadi, A (2011). Spatial Distribution of Lead in Calcareous Soils and Rice Seeds of Khuzestan, Iran, Malay. J. Soil. Sci. 15:115-125.

Chessebrough, M (2000). Disrict Laboratory Pactice in Troppical Countries, Part 2, Cambridge low Price Edition, Cambridge University Press, London.

Cleiton, A; Nunese, N; Guerreiro, C (2011). Estimation of Surface Area and Pore Volume of Activated Carbon by Methylene Blue and Iodine Numbers. Qui. Nov. 34(3):472-476.

Cowan, ST (1993). Cowan and Steels Manual for the Identification of Medical Bacteria, Cambridge University Press, London.

Cowan, ST; Steel, R (1990). Manual for the Identification of Medical Bacteria, Cambridge University Press, London.
Galiulin, RV; Bashkin, VN; Galiulina, RA; Kucharski R (2002). Airborne Soil Contamination by Heavy Metals in Russia and Poland, and its Remediation, Lan. Contam, Reclam. 10(3):179-187.

Holt, JC (ED) (1994). The Shorter Bergeys Manual of Determinative Bacteriology, Eight Edition, Williams and Willkins Company, Baltimore.

Lenntech, WT (2009). Chemical Properties, Health and Environmental Effects of Copper, Lenntech Water Treatment and Purification, Holding B.V. www.lenntech.com/periodic/elements/cu.htm, accessed on $14^{\text {th }}$ January, 2010.

Lima, EC; Royer, B; Vaghetti, JCP; Brasil, JL; Simon, NM; Dos Santos Jr., AA; Pavan, FA; Dias, SLP; Benvenutti, EV Da Silva, EA (2007). Adsorption of $\mathrm{Cu}$ (II) on Araucaria Angustifoliawastes: Determination of the Optimal Conditions by Statistic Design of Experiments. J. Hazard. Mate. 140:211220.

Mukesh, K; Raikwar, Kumar, P; Singh, M; Singh A (2008). Toxic Effect of Heavy Metals in Livestock Health, Veteran. Work. 1(1):28-30.

Narayanan, P (2007). Environmental Pollution, Principles, Analysis and Control, CBS Publishers and Distributors PVT. LTD, New Delhi, India.

Njoku, C; Ngene, PN (2012). Content and Distribution of Heavy Metals in an Abandoned Mechanjc and NonMechanic Sites in Abakaliki, Southeastern Nigeria. Greener J. Phys. Sci. 2(1):016-019.

Nwaugo, VO; Onyeagba, RA; Akubugwo, EI; Ugbogu, S (2008). Soil Bacterial Flora and Enzymatic Activities in Zinc and Lead Contaminated Soil. BIOKEMI. 20(2):77-84.

Okoronkwo, NB; Igwe, JC; Onwuchekwa, EC (2005). Risk and Health Implications of Polluted Soils for Corp Production. Afr. J. Biotech. 4(13):1521-1524.

Pavan, FA; Gushikem, Y; Mazzocato, AC; Dias, SLP; Lima, EC (2007). Statistical design of Experiments as a Tool for Optimizing the Batch Conditions to Methylene Blue Biosorption on Yellow Passion Fruit and Mandarin Peels, Dy. Pigment. 72:256-266.

Vousta, D; Grimanins, A; Sammara, C (1996). Trace Elements in Vegetable Grown in an industrial area in Relation to Soil and Air Particulate Matter. Environ. Pollute. 94(3):325-335. 